\title{
Is D-methionine bioavailable to the dairy cow?
}

\author{
H. Lapierre, ${ }^{\star 1}$ G. Holtrop,† A. G. Calder,‡ J. Renaud, ${ }^{\star}$ and G. E. Lobley‡ \\ ${ }^{*}$ Dairy and Swine Research and Development Centre, Agriculture and Agri-Food Canada, Sherbrooke, QC, Canada, J1M 0C8 \\ †Biomathematics and Statistics Scotland (BioSS), Aberdeen, AB21 9SB, United Kingdom \\ $\ddagger$ Rowett Institute of Nutrition and Health, University of Aberdeen, Aberdeen, AB21 9SB, United Kingdom
}

\begin{abstract}
Rumen-protected forms of Met contain an equimolar mixture of the D- and L-isomers. Only L-Met can be directly used for protein synthesis, but it is unclear how much of the D-isomer can be transformed into L-Met in ruminants. Four lactating dairy cows, with an average milk yield of $32.4 \mathrm{~kg} / \mathrm{d}$, received a basal diet $(12.5 \%$ crude protein, supplying $1,718 \mathrm{~g} / \mathrm{d}$ of metabolizable protein) in 12 equal meals per day plus an abomasal infusion of amino acids $(590 \mathrm{~g} / \mathrm{d}$, casein profile without Met). They were used in 3 consecutive studies to determine utilization of D-Met. First, the cows each received portal vein infusions for $2 \mathrm{~d}$ of 5,10 , or $15 \mathrm{~g} / \mathrm{d}$ of DLMet in a Youden square. On the last day of each period, 6 arterial samples were collected at 45-min intervals. Concentrations of L- and D-Met were determined on a chiral column by gas chromatography-mass spectrometry. Portal infusion of 5, 10, and $15 \mathrm{~g} / \mathrm{d}$ of DL-Met increased plasma total Met concentrations (19.7, 25.0, and $34.4 \pm 0.6 \mu M)$ and the proportion of Met as D (19.4, 30.5, and $37.3 \pm 0.7 \%)$. The fractional removal of D-Met was 6 to 7 times lower than the fractional removal of L-Met, with mean half-lives of 52 versus 8 min, respectively. Second, the same cows were infused for $8 \mathrm{~h}$ with $\mathrm{L}\left[\right.$ methyl $\left.-{ }^{2} \mathrm{H}_{3}\right]$ Met at $1.3 \mathrm{mmol} / \mathrm{h}$; at $2 \mathrm{~h}$, cows received a bolus injection i.v. of D- $\left[1-{ }^{13} \mathrm{C}\right]$ Met $(6.8$ mmol), and arterial samples were collected after 10 , 20, 30, 40, 60, 90, 120, 150, 180, 240, 300, 360, 420, and $480 \mathrm{~min}$. Expressed relative to $\mathrm{L}-\left[{ }^{12} \mathrm{C}\right] \mathrm{Met}$; that is, as tracer:tracee ratios, enrichments of plasma D- $\left[1-{ }^{13} \mathrm{C}\right]$ Met and L- $\left[1-{ }^{13} \mathrm{C}\right]$ Met averaged $1.77 \pm 0.14$ and $0.144 \pm$ 0.026 , respectively, $10 \mathrm{~min}$ after the bolus injection and declined exponentially thereafter. A minimum of $75 \pm$ $3 \%$ of the $\mathrm{D}-\left[1-{ }^{13} \mathrm{C}\right]$ Met was transformed into $\mathrm{L}-\left[1-{ }^{13} \mathrm{C}\right]$ Met. Third, the cows received, in a crossover design, an abomasal infusion for $5 \mathrm{~d}$ of either DL-Met or L-Met (15 $\mathrm{g} / \mathrm{d}$ ) and, on the last day of each experimental period, blood samples were collected simultaneously from arterial, portal, hepatic, and mammary vessels. Arterial
\end{abstract}

Received May 19, 2011.

Accepted September 12, 2011.

${ }^{1}$ Corresponding author: Helene.Lapierre@agr.gc.ca total Met concentrations were higher with DL- versus L-Met infusions (37.4 vs. $25.4 \pm 0.5 \mu M$ ), with $37.1 \pm$ $5.0 \%$ as D-Met. The mammary gland did not extract any D-Met. Hepatic removal of D-Met was observed, but was numerically lower than the fractional extraction of L-Met. In conclusion, much of the D-Met is transformed into L-Met by the dairy cow but at a slow rate. No uptake of D-Met occurs across the mammary gland but L-Met synthesized from the D-isomer elsewhere in the body can be utilized for milk protein synthesis.

Key words: D-methionine, L-methionine, stable isotope, mammary gland

\section{INTRODUCTION}

Over the last 2 decades, special attention has been devoted to Lys and Met requirements for lactating dairy cows because both AA are recognized as often being first-limiting in the rations fed under intensive North American or European systems (Rulquin et al., 1993; Schwab, 1996). To overcome Met deficiency, commercial supplements of rumen-protected Met have been developed (see reviews: Patton, 2010; Robinson, 2010). The chemical synthesis involved results in a racemic mixture of the D- and L-enantiomers of Met. As with other AA, only the L-isomer of Met can be incorporated into mammalian proteins. Therefore, the bioavailability of D-Met depends on the rate of transformation into L-Met. Such conversion in mammals involves D-amino acid oxidase that deaminates D-Met to yield the oxo(keto-) acid, 2-oxo-4-methylthiobutanoate. This can then be reaminated to the L-form (Friedman and Gumbmann, 1989).

The bioavailability of D-Met has been extensively studied in many species (see Lewis and Baker, 1995), and rats, chicks, pigs, rabbits, and dogs all demonstrate good conversion to L-Met when D-Met is administered by either oral or i.v. routes, although this is not the case with primates (Stegink, 1983; Lewis and Baker, 1995). For ruminants, data are scarce and somewhat equivocal. For example, in sheep, lower utilization of D-Met than L-Met has been reported for both $\mathrm{N}$ and $\mathrm{S}$ retention (Doyle, 1981) although they appear equally effective for 
support of wool growth (Doyle, 1981; Reis et al., 1989). In growing cattle, D- and L-Met produced similar increases in N retention (Campbell et al., 1996) although this tended to be lower with DL-Met infusion compared with an equimolar dose of L-Met (Titgemeyer and Merchen, 1990). In both these bovine studies, plasma total Met concentrations (D plus L) were substantially greater when either D- or DL-Met was provided compared with similar supplementation of the L-enantiomer. Indeed, measurement of the 2 enantiomers, through use of a chiral column, demonstrated unequivocally that feeding rumen-protected Met to dairy cows led to accumulation of D-Met in the plasma (Lobley et al., 2001). In most studies, the effectiveness of D-Met has been assessed through biological responses under conditions where the anabolic improvement can be achieved by either limited conversion of D-Met to the L-isomer or through direct use of the L-Met present in the racemic mixture provided. Such observations, coupled with preliminary data from dairy cows that indicated that the mammary gland did not extract D-Met (H. Lapierre and G. E. Lobley, unpublished results), raised questions about the true availability of the D-Met for milk protein synthesis in dairy cows.

The first hypothesis investigated was that although D-Met is converted to the L-isomer in dairy cows, this occurs at a slower rate than removal of L-Met and leads to accumulation of D-Met in plasma. A second hypothesis was that a proportion of the removal of DMet involved conversion to L-Met. The third hypothesis was that conversion of D- to L-Met does not occur in the mammary gland, so that any benefits from D-Met supplementation for milk protein synthesis would rely on metabolism to L-Met in other tissues, such as liver. These hypotheses were tested in multi-catheterized cows, with stable isotopes and chiral column analysis, to quantify metabolism of D-Met to L-Met at levels of supplementation provided under normal husbandry practice.

\section{MATERIALS AND METHODS}

\section{Animals and Treatments}

Four multiparous Holstein cows, averaging $( \pm \mathrm{SEM})$ $662 \pm 21 \mathrm{~kg}$ of BW and $143 \pm 10$ DIM at the beginning of the experiment, were used in 3 studies. Cows had been surgically implanted with abomasal catheters (Doepel et al., 2006) and with chronic indwelling catheters in the mesenteric, portal, and hepatic veins plus the caudal aorta via a mesenteric artery (Huntington et al., 1989), at least 6 mo before the initiation of the project. The right carotid artery was surgically raised to a subcutaneous position to allow access to arterial blood if the aorta catheter lost patency.
Throughout the studies, milk production averaged $32.4 \pm 2.5 \mathrm{~kg} / \mathrm{d}$ at $3.02 \pm 0.10 \% \mathrm{CP}$ and $4.51 \pm 0.31 \%$ fat from a DMI of $20.8 \pm 0.5 \mathrm{~kg} / \mathrm{d}$. Cows were fed a fixed intake of a single diet (Tables 1 and 2) at a DMI corresponding to $97 \%$ of ad libitum intake measured the week before initiation of the project. This supplied $101 \%$ of net energy requirement but only $80 \%$ of requirement for MP (NRC, 2001). In addition, throughout the 3 studies, cows received an abomasal infusion (Table 3) of an AA mixture based on casein profile excluding Met but with an adjustment to raise the proportion of essential AA to $50 \%$ of the AA infused. Due to solubility constraints, Tyr was replaced by Phe and part of Glu was replaced by Gln. The AA were dissolved in hot water as batches every 2 or $3 \mathrm{~d}$. The AA infusions were administered continuously at $6 \mathrm{~L} / \mathrm{d}$ with a peristaltic pump and increased the MP supply (excluding Met) to $108 \%$ of requirements (NRC, 2001). The TMR was fed in 12 equal meals per day delivered at 2-h intervals by automatic feeders (Ankom, Fairport, NY). Orts, when present, were recorded and sampled daily. Moisture content of the silages was determined weekly and was used to make ration adjustments to ensure constant delivery of DM. Cows were given free access to fresh water. Cows were milked twice a day, at 0730 and $1930 \mathrm{~h}$, and milk yield was recorded at each milking. Milk was sampled at each milking on the last $2 \mathrm{~d}$ of each experimental period of the third study. The experimental protocol was approved by the Institutional Committee for Animal Care of the Lennoxville Research Centre and animals were cared for in accordance with the guidelines of the Canadian Council on Animal Care (1993).

Study 1. The 4 cows were used in a $3 \times 3$ Youden square design, with 3 treatments and 3 experimental periods. Each period lasted $2 \mathrm{~d}$ and the treatments involved portal infusion of DL-Met (50.3\% L; Sigma, St.

Table 1. Ingredient and nutrient composition of the TMR fed to the cows through the study

\begin{tabular}{lc}
\hline Item & Amount \\
\hline Ingredient (\% of DM) & \\
Corn silage & 40.4 \\
High moisture corn & 25.2 \\
Grass hay & 21.3 \\
Roasted soybeans & 7.1 \\
Urea & 0.3 \\
Ca soap of fatty acids ${ }^{1}$ & 1.8 \\
Mineral and vitamin premix & 3.9 \\
Estimations from NRC (2001) & \\
NE $($ Mcal/d) & 35.7 \\
CP (\% DM basis) & 12.5 \\
MP (g/d) & 1,718 \\
\hline
\end{tabular}

${ }^{1}$ Megalac, Church \& Dwight Co. Inc. (Princeton, NJ).

${ }^{2}$ Estimated from the measured DMI through the project. 
Table 2. Chemical composition of the feed ingredients (\% of DM)

\begin{tabular}{lrrrr}
\hline Analysis & $\begin{array}{c}\text { Corn } \\
\text { silage }\end{array}$ & $\begin{array}{c}\text { High-moisture } \\
\text { corn }\end{array}$ & $\begin{array}{c}\text { Grass } \\
\text { hay }\end{array}$ & $\begin{array}{c}\text { Roasted } \\
\text { soybeans }\end{array}$ \\
\hline CP & 8.5 & 10.1 & 12.5 & 43.4 \\
ADF & 18.2 & 3.2 & 37.4 & 10.2 \\
NDF & 30.0 & 10.9 & 63.9 & 11.6 \\
Lipid & 3.2 & 6.1 & 2.2 & 21.6 \\
Ash & 3.3 & 1.5 & 6.1 & 5.5 \\
\hline
\end{tabular}

Louis, MO) at 5, 10, or $15 \mathrm{~g} / \mathrm{d}$, always in addition to the abomasal infusion of the AA mixture. On the last day of each experimental period, starting at 0800 h, 6 blood samples were collected from the arterial catheter into heparinized tubes every $45 \mathrm{~min}$ for $4 \mathrm{~h}$, covering 2 feeding cycles. Plasma concentrations of Met and proportions of D- and L-Met were analyzed as described below.

Study 2. On the evening after the last period of study 1, the infusions of DL-Met were stopped. The following morning, the 4 cows received, through the hepatic catheter, a primed $(1.3 \mathrm{mmol})$ continuous $(1.3$ $\mathrm{mmol} / \mathrm{h}$ ) infusion of $\mathrm{L}-\left[\right.$ methyl- $\left.{ }^{2} \mathrm{H}_{3}\right]$ Met (Cambridge Isotope Labs, Andover, MA) for $10 \mathrm{~h}$ (from 0600 to $1600 \mathrm{~h})$. At $2 \mathrm{~h}$ after the initiation of this infusion, D- $\left[1-{ }^{13} \mathrm{C}\right]$ Met $(6.9 \mathrm{mmol} ; 1 \mathrm{~g})$ was injected into the portal catheter. Blood samples were collected from the arterial catheter 10, 20, 30, 40, 50, 60, 90, 120, 150, 180, 240, 300, 360, 420, and $480 \mathrm{~min}$ after the bolus injection. Plasma concentrations and isotopic enrichments (IE; D- and L- $\left[1-{ }^{13} \mathrm{C}\right]$ Met and [methyl- $\left.{ }^{2} \mathrm{H}_{3}\right]$ Met) of Met and proportions of D- and L-Met were analyzed as described below.

Study 3. In a crossover design with two 5-d experimental periods, the same 4 cows received, in addition to the abomasal infusion of the AA mixture, an abomasal infusion of $15 \mathrm{~g} / \mathrm{d}$ of either L-Met or DL-Met (Sigma). On d 5 of each experimental period, starting at 0800 h, 6 blood samples were collected simultaneously into heparinized tubes from the arterial, hepatic venous and portal catheters every $45 \mathrm{~min}$ for $4 \mathrm{~h}$, covering 2 feeding cycles. Blood samples were also obtained from the subcutaneous abdominal vein by venipuncture following the same 45-min sampling schedule. Concentrations of Met and proportions of D- and L-Met were analyzed as described below.

\section{Samples Processing and Laboratory Analyses}

Immediately after collection, all blood samples were placed on ice and centrifuged $(15 \mathrm{~min}, 1,800 \times g$ at $4^{\circ} \mathrm{C}$ ) within $30 \mathrm{~min}$ to yield plasma. To determine Met concentration, $1 \mathrm{~g}$ of plasma was immediately added to $0.2 \mathrm{~g}$ of an internal standard of AA labeled with stable isotopes. The internal standard solution was prepared with labeled AA diluted in water and included DL- 1 $\left.{ }^{13} \mathrm{C}\right]$ Met (Cambridge Isotope Lab). Plasma samples were stored at $-80^{\circ} \mathrm{C}$.

Feed ingredients and milk samples were analyzed as described previously (Lapierre et al., 2009). Plasma concentrations of Met were measured by isotope dilution using GC-MS (model GC6890-MS5973; Agilent Technologies, Wilmington, DE) as described previously by Calder et al. (1999). The IE of L- $\left[\right.$ methyl- $\left.{ }^{2} \mathrm{H}_{3}\right]$ Met and both $\mathrm{D}-$ and $\mathrm{L}-\left[1-{ }^{13} \mathrm{C}\right]$ Met were also determined (Calder and Smith, 1988) using the same GC-MS system. Briefly, concentrations and IE of plasma Met were determined after deproteinization with sulfosalicylic acid and derivatization with $N$-(t-butyldimethysilyl)$N$-methyltrifluoroacetate:acetronile (1:1) to produce t-butyldimethylsilyl (tBDMS) derivatives and then monitoring $\mathrm{m} / \mathrm{z}$ ions 320 and 321 for Met concentrations and $m / z$ ions 320,321 , and 323 for Met IE. Where appropriate, corrections were applied for any $m+1$ ion present from the infusion in the estimation of the concentration. The enrichment of plasma $\left[1-{ }^{13} \mathrm{C}\right]$ homocysteine (HCys) was determined as the tBDMS derivative with $m / z$ ions of the $m-57$ fragment monitored at 420

Table 3. Composition of the abomasal infusion of AA

\begin{tabular}{lc}
\hline AA & $\mathrm{g} / \mathrm{d}$ \\
\hline Ala & 17.7 \\
Arg & 20.6 \\
Asn & 22.5 \\
Asp & 18.2 \\
Cys & 3.7 \\
Gln & 89.1 \\
Glu & 25.9 \\
Gly & 9.6 \\
His & 15.2 \\
Ile & 35.7 \\
Leu & 59.3 \\
Lys & 50.3 \\
Met & 0 \\
Phe & 59.6 \\
Pro & 53.5 \\
Ser & 33.7 \\
Thr & 26 \\
Trp & 9.1 \\
Val & 40 \\
\hline
\end{tabular}


and 421, as described previously (Wilson et al., 2009; Voyager GCMS system, Thermoquest Ltd., Hemel Hempstead, UK). D- and L-Methionine isomers were separated as $i$-butyl heptafluorobutyryl derivatives on a $30-\mathrm{m} \times 0.25-\mathrm{mm} \times 0.12-\mu \mathrm{m}$ Chirasil-L-Val capillary column. The proportions of natural abundance $(m+0)$ and labeled $(m+1$ and $m+3)$ for each of D- and L-Met were determined from the sum of ion areas at $\mathrm{m} / \mathrm{z}$ 401.2, 402.2, and 404.2 measured under electron impact selective ion monitoring (EI-SIM) conditions on a Voyager GCMS system (Thermoquest Ltd.).

\section{Calculations and Statistical Analysis}

For the first study, the fractional rate constants for the D- and L-Met $\left(\mathbf{k}_{\mathrm{D}}\right.$ and $\mathbf{k}_{\mathrm{L}}$, respectively) were calculated from rate of appearance (Ra) divided by pool size. The Ra of D-Met was assumed equal to the rate of infusion, whereas the Ra of L-Met was taken from the whole-body (WB) Ra estimated in study 2 plus the infusion rate of L-Met. The pool size was calculated as the distribution space (estimated in study 2) multiplied by the respective concentrations of D- and L-Met.

For the second study, all the IE $\left(\mathrm{D}-\left[1-{ }^{13} \mathrm{C}\right] \mathrm{Met}, \mathrm{L}-[1-\right.$ $\left.{ }^{13} \mathrm{C}\right]$ Met, L- $\left[\right.$ methyl- $\left.{ }^{2} \mathrm{H}_{3}\right]$ Met and $\left.\left[1-{ }^{13} \mathrm{C}\right] \mathrm{HCys}\right)$ were expressed relative to $\left[{ }^{12} \mathrm{C}\right] \mathrm{Met}$; that is, as tracer:tracee ratio (TTR). To correct for small fluctuations in the $\left[{ }^{12} \mathrm{C}\right]$ Met pool size, the observed IE of the D- $\left[1-{ }^{13} \mathrm{C}\right]$ and $\mathrm{L}-\left[1-{ }^{13} \mathrm{C}\right]$ Met were multiplied by the ratio of the average to the observed IE of L- $\left[\right.$ methyl- $\left.{ }^{2} \mathrm{H}_{3}\right]$ Met. The WB Ra of $\mathrm{L}-\left[{ }^{12} \mathrm{C}\right]$ Met (tracee) was calculated as

$$
\begin{gathered}
\text { WB } \operatorname{Ra}_{\mathrm{L}-[12 \mathrm{C}] \mathrm{Met}}(\mathrm{mmol} / \mathrm{h})=\text { infusion rate } \\
(\mathrm{mmol} / \mathrm{h}) / \text { arterial } \mathrm{IE}_{\mathrm{L}-\mathrm{Met}},
\end{gathered}
$$

with the infusion rate of L- $\left[\right.$ methyl- $\left.{ }^{2} \mathrm{H}_{3}\right]$ Met and the average of the IE of arterial plasma L- $\left[\right.$ methyl- $\left.{ }^{2} \mathrm{H}_{3}\right] \mathrm{Met}$ collected starting $2 \mathrm{~h}$ after the initiation of the infusion. It should be noted that the Ra based on IE of plasma L-[methyl- $\left.{ }^{2} \mathrm{H}_{3}\right]$ Met will exceed that based on $\mathrm{L}-\left[1-{ }^{13} \mathrm{C}\right]$ Met due to methylation of HCys within the Met cycle. For sheep and dairy cows, the overestimate varies between 6 and 14\% (Lobley et al., 1996; Preynat et al., 2009). In practice, any Ra based on plasma will underestimate the true flux; instead, the intracellular pool should be used as the precursor. For example, use of plasma HCys derived from tissue Met cycle activity would increase Ra by 30 to $40 \%$ in sheep (Lobley et al., 2003). Therefore, the following estimates of conversion of D- to L-Met remain conservative estimates.

To estimate disappearance of injected $\mathrm{D}-\left[1-{ }^{13} \mathrm{C}\right] \mathrm{Met}$ and rate of appearance of $\mathrm{L}-\left[1-{ }^{13} \mathrm{C}\right]$ Met, a double expo- nential model (Shipley and Clark, 1972) was applied, where

$$
\mathrm{IE}_{\mathrm{D}-\mathrm{Met}}(\mathrm{t})=\mathrm{A}_{1} \exp \left(-\mathrm{g}_{1} \mathrm{t}\right)+\mathrm{A}_{2} \exp \left(-\mathrm{g}_{2} \mathrm{t}\right),
$$

where $\mathrm{t}$ represents the time in minutes, and $\mathrm{A}$ and $\mathrm{g}$ are constant.

The pool size of the L- $\left[{ }^{12} \mathrm{C}\right]$ Met can be estimated from this equation at $\mathrm{t}=0$, as the $\mathrm{IE}$ are expressed relative to L- $\left[{ }^{12} \mathrm{C}\right]$ Met:

$$
\text { Pool size }=\text { dose of } \mathrm{D}-\left[1-{ }^{13} \mathrm{C}\right] \mathrm{Met} /\left(\mathrm{A}_{1}+\mathrm{A}_{2}\right)
$$

and the distribution space $=$ pool size $/\left[{ }^{12} \mathrm{C}\right]$ Met concentration.

The proportion of $\mathrm{D}-\left[1-{ }^{13} \mathrm{C}\right]$ Met converted to $\mathrm{L}-\left[1-{ }^{13} \mathrm{C}\right]$ Met administered was determined from

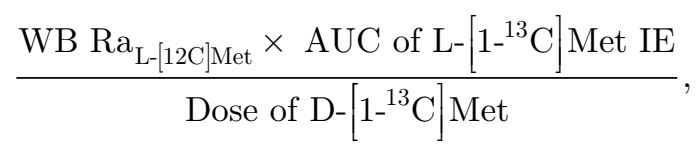

where $\mathrm{AUC}=$ area under the curve. This assumes (1) that the amount of $\mathrm{L}-\left[1-{ }^{13} \mathrm{C}\right]$ Met appearing in the plasma $=$ the amount disappearing from the plasma; that is,

$$
\begin{aligned}
& =\int \mathrm{k}_{\mathrm{L}} \mathrm{q}_{\mathrm{L}}(\mathrm{t}) \mathrm{dt} \\
& =\mathrm{k}_{\mathrm{L}} \text { pool size } \mathrm{si}_{\mathrm{L}} \int \mathrm{IE}_{\mathrm{L}}(\mathrm{t}) \mathrm{dt} \\
& =\text { WB Ra }{ }_{\mathrm{L}-[12 \mathrm{C}] \text { Met }} \times \mathrm{AUC} \text { of L- }\left[1-{ }^{13} \mathrm{C}\right] \text { Met IE, }
\end{aligned}
$$

and (2) that total $\mathrm{D}-\left[1-{ }^{13} \mathrm{C}\right]$ Met disappearance from the plasma equals the bolus dose administered.

In the third study, the mammary gland fractional extraction rate was calculated as arterio-venous concentration difference divided by arterial concentrations. Liver extraction ratio was calculated relative to total liver inflow assuming that hepatic arterial plasma flow represented $17 \%$ of liver plasma flow, as observed for the same cows in a previous experiment (Lapierre et al., 2009). Therefore, liver extraction ratio was calculated as $[(\mathrm{A}-\mathrm{H}) \times 0.17+(\mathrm{P}-\mathrm{H}) \times 0.83] /(\mathrm{A} \times 0.17+\mathrm{P}$ $\times 0.83)$, where $\mathrm{A}, \mathrm{P}$, and $\mathrm{H}$ represent arterial, portal, and hepatic concentrations, respectively, for L- and DMet as appropriate.

For studies 1 and 3, data were averaged by cow $\times$ period and statistically analyzed using the GLM procedure of SAS (SAS Institute, 2008) with treatment, period, and cow as the main effects according to the Youden square design and the crossover, respectively. For the first study, treatments were compared using polynomial 
Table 4. Methionine concentrations during portal infusion of various doses (5, 10, or $15 \mathrm{~g} / \mathrm{d})$ of DL-Met in dairy $\operatorname{cows}^{1}$ (study 1)

\begin{tabular}{|c|c|c|c|c|c|c|}
\hline \multirow[b]{2}{*}{ Item } & \multicolumn{3}{|c|}{ Dose of DL-Met $(\mathrm{g} / \mathrm{d})$} & \multirow[b]{2}{*}{ SEM } & \multicolumn{2}{|c|}{$P$-value ${ }^{2}$} \\
\hline & 5 & 10 & 15 & & Linear & Quadratic \\
\hline Total concentration $(\mu M)$ & 19.7 & 25.0 & 34.4 & 0.6 & $<0.001$ & 0.04 \\
\hline D $(\%)$ & 19.4 & 30.5 & 37.3 & 0.7 & $<0.001$ & 0.06 \\
\hline D:L & 0.24 & 0.45 & 0.60 & 0.02 & $<0.001$ & 0.46 \\
\hline D concentration $(\mu M)$ & 3.8 & 7.7 & 12.8 & 0.5 & $<0.001$ & 0.30 \\
\hline L concentration $(\mu M)$ & 15.9 & 17.3 & 21.6 & 0.5 & 0.001 & 0.06 \\
\hline Total pool (mmol) & 4.33 & 5.51 & 7.56 & 0.11 & $<0.001$ & 0.04 \\
\hline D pool (mmol) & 0.85 & 1.70 & 2.82 & 0.11 & $<0.001$ & 0.38 \\
\hline L pool (mmol) & 3.48 & 3.81 & 4.74 & 0.08 & 0.001 & 0.04 \\
\hline Fractional removal of D-Met $(/ \mathrm{h})$ & 0.83 & 0.83 & 0.75 & 0.01 & 0.008 & 0.07 \\
\hline Fractional removal of L-Met $(/ \mathrm{h})$ & 5.89 & 5.54 & 4.60 & 0.09 & $<0.001$ & 0.06 \\
\hline
\end{tabular}

(linear and quadratic) contrasts: with 3 treatments, a linear contrast compares the difference between the first and last levels for significance, whereas significance for the quadratic contrast indicates the lack of fit of the intermediary level for a linear relationship (Gill, 1978). In the third study, when the proportion and concentrations of D-Met were compared across sites, data were analyzed with GLM with cow and site as the main effects. Treatment differences were considered significant if $P \leq 0.05$ and as a tendency with $0.05<P \leq 0.10$. All data are reported as LSM with pooled SEM. For the second study, data are reported for each cow, as no treatment was applied.

\section{RESULTS AND DISCUSSION}

\section{Study 1}

Linear contrasts $(P<0.001)$ were observed for plasma concentrations of D-, L-, and total Met as the dose of DL-Met increased. In addition, quadratic contrasts were observed for total $(P=0.04)$ and L-Met concentrations $(P=0.06)$ with a greater increase between 10 and $15 \mathrm{~g} / \mathrm{d}$ than between 5 and $10 \mathrm{~g} / \mathrm{d}$ infusion rates (Table 4 ). Therefore, the proportion of total Met as the D-isomer altered with both linear $(P<0.001)$ and quadratic $(P=0.06)$ contrasts. The $\mathrm{D}: \mathrm{L}$ ratio in plasma concentrations increased linearly $(P<0.001)$ and reached 0.60 at the highest rate of infusion (Table 4). This high proportion of D-Met was obtained with an infusion rate of $7.5 \mathrm{~g}$ of D-Met, which was only $20 \%$ of the corresponding L-Met exogenous supply, estimated at $39.5 \mathrm{~g} / \mathrm{d}$; that is, the sum of the digestible flow (32 $\mathrm{g} / \mathrm{d}$; NRC, 2001) plus the infusion rate of $7.5 \mathrm{~g} / \mathrm{d}$. A Disomer contribution of $50 \%$ to total Met in the plasma of dairy cows fed rumen-protected DL-Met has already been reported (Lobley et al., 2001). Such accumulation of D-Met probably explains the higher plasma total Met concentrations in growing cattle supplemented with either D- or DL-Met compared with L-Met (Titgemeyer and Merchen, 1990; Campbell et al., 1996).

These observations indicate that the rate of removal for the D-isomer is slower than that for the L-isomer. Indeed, estimated rates of removal of the L-isomer were more than 6-fold faster than for the D-isomer (Table $4)$. Corresponding half-lives, estimated as $\ln (2) /$ rate of removal, ranged from 50 to $55 \mathrm{~min}$ for D-Met compared with 7 to 9 min for L-Met.

\section{Study 2}

Although the different rates of $\mathrm{k}_{\mathrm{L}}$ and $\mathrm{k}_{\mathrm{D}}$ explain the accumulation of the D-enantiomer, relative to $\mathrm{L}$ Met, in plasma this provides no information on how the D-Met is metabolized, either oxidized or converted to L-Met. That the latter occurred was demonstrated unequivocally with the stable isotope procedure. Figure 1 shows appearance of $\mathrm{L}-\left[1-{ }^{13} \mathrm{C}\right]$ Met concomitant with disappearance of $\mathrm{D}-\left[1-{ }^{13} \mathrm{C}\right]$ Met, with $75 \pm 3 \%$ conversion (Table 5). This is a minimum conversion efficiency as, in addition to the comments made in the section on Calculations and Statistical Analysis, only L-Met synthesized intracellularly and released as free Met into the plasma is quantified by this approach. Any L- $\left[1-{ }^{13} \mathrm{C}\right]$ Met synthesized and then used within a cell will not be included. The continued, but slow, rate of intracellular conversion of D- to L-Met is reflected by the appearance in plasma of $\mathrm{L}-\left[1-{ }^{13} \mathrm{C}\right] \mathrm{HCys}$ at an IE that exceeds that of $\mathrm{L}-\left[1-{ }^{13} \mathrm{C}\right]$ Met at the later times (Figure $\left.1 \mathrm{~b}\right)$. The fractional turnover of HCys is of comparable magnitude to that of L-Met in other species (Wilson et al., 2009) and the HCys released into plasma at high enrichment must derive from a precursor source of similar or higher enrichment. Clearly this is not endogenous L-Met (as 


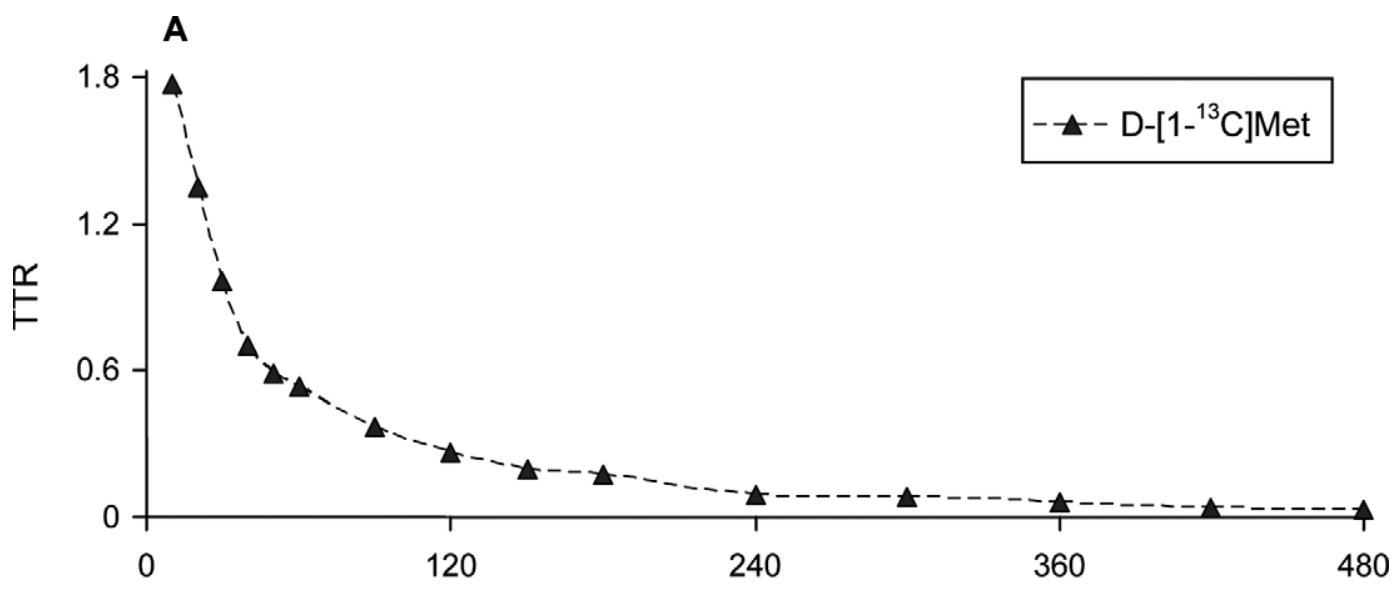

B

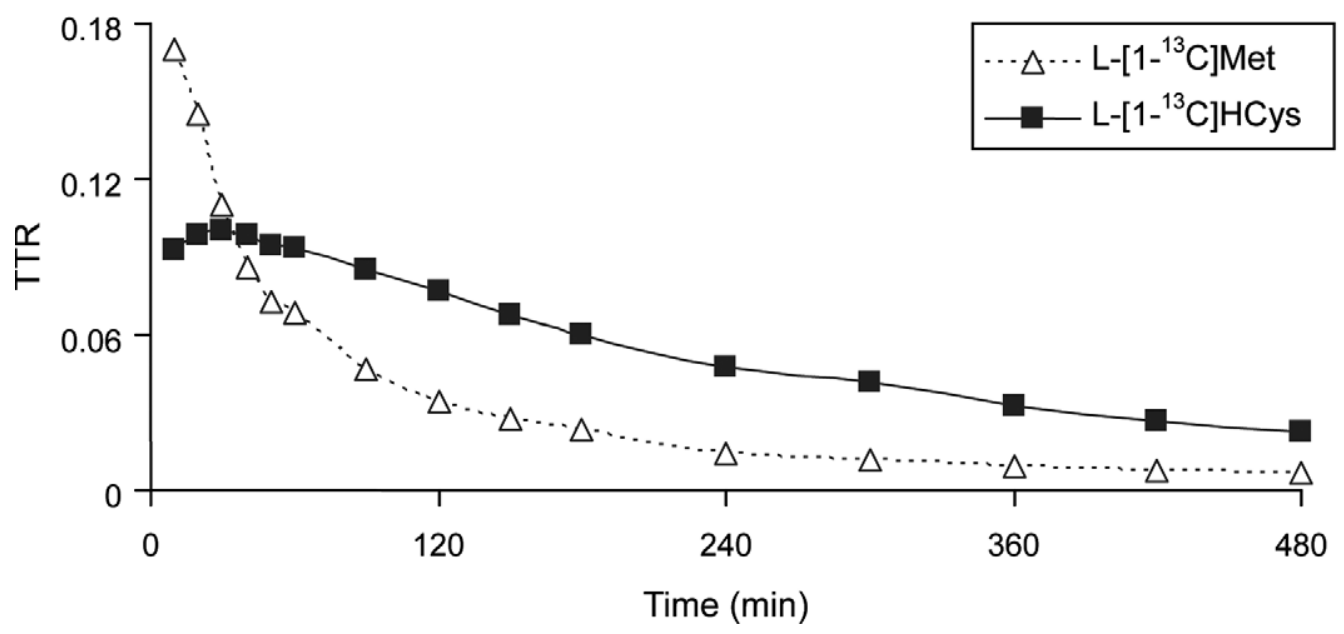

Figure 1. Tracer to tracee ratio (TTR; expressed relative to L- $\left.\left[{ }^{12} \mathrm{C}\right] \mathrm{Met}\right)$ for $(\mathrm{A}) \mathrm{D}-\left[1{ }^{13} \mathrm{C}\right] \mathrm{Met}$ and $(\mathrm{B}) \mathrm{L}_{-}\left[1-{ }^{13} \mathrm{C}\right] \mathrm{Met}$ and L- $\left[1{ }^{13} \mathrm{C}\right]$ homocysteine (HCys), after a bolus injection of D- $\left[1-{ }^{13} \mathrm{C}\right]$ Met in dairy cows (study 2 ).

shown by the plasma enrichments) and so must be from D-Met converted to L-Met that then enters the Met cycle. Part of this HCys may enter the trans-sulfuration pathway and not contribute to L-Met that is exported to plasma. This metabolic route, plus utilization of L-Met produced within the cell and used for protein synthesis (Wilson et al., 2009), will contribute further to the underestimation of D- to L-Met inter-conversion based on plasma measurements. Such underestimates have also been reported for the hydroxyl analog of Met, DL-2-hydroxy-4-methylthiobutyrate, that also undergoes racemic conversion and synthesis to L-Met in vivo within a variety of sheep tissues (Lobley et al., 2006). Therefore, the current data indicate that most of the dose of D-Met was transformed into L-Met and this occurred within $3 \mathrm{~h}$ (see Figure 1). Scaling that to a 24-h period, sufficient enzymatic activity would exist to transform approximately $6.5 \mathrm{~g}$ of D-Met daily, within the range of D-Met provided by commercial rumen-protected Met products under normal husbandry, acknowledging that such supplements will deliver Met throughout the day (Lapierre et al., 2002). This potential capacity is also supported by study 1 in which fractional removals $\left(\mathrm{k}_{\mathrm{D}}\right)$ were maintained as $\mathrm{D}$ Met supplementation was increased 3-fold. The current studies do not provide an upper limit for the rate of conversion of D- to L-Met, however.

The rate of removal $\left(\mathrm{k}_{\mathrm{D}}\right)$ of $\mathrm{D}-\mathrm{Met}$, measured directly within study 2 was greater than estimated from study 1 (1.34 vs. $\left.0.80 \mathrm{~h}^{-1}\right)$, with a mean half-life of $31 \mathrm{~min}$. The differences in $k_{D}$ between the 2 studies may exist for several reasons, including the assumption in study 1 that the distribution volumes of D- and L-Met are identical. Nonetheless, in both study 1 and study 2 , the rate of removal of the L-Met was, on average, 6 to 7 times faster than the rate of removal of the D-Met. Fur- 
Table 5. Methionine kinetics parameters in dairy cows estimated from a continuous infusion of L- $\left[\right.$ methyl- $\left.{ }^{2} \mathrm{H}_{3}\right]$ Met and a bolus injection of D- $\left[1-{ }^{13} \mathrm{C}\right]$ Met (study 2$)$

\begin{tabular}{lcccc}
\hline Cow & $\begin{array}{c}\text { WB Ra } \\
(\mathrm{mmol} / \mathrm{h})\end{array}$ & $\begin{array}{c}\text { App. L-Met/ } \\
\text { Dis. D-Met }\end{array}$ & $\begin{array}{c}\mathrm{k}_{\mathrm{D}}{ }^{3} \\
(/ \mathrm{h})\end{array}$ & $\begin{array}{c}\mathrm{k}_{\mathrm{L}}{ }^{3} \\
(/ \mathrm{h})\end{array}$ \\
\hline 2010 & 17.4 & 0.68 & 1.22 & 6.74 \\
2047 & 21.3 & 0.79 & 1.10 & 7.04 \\
5274 & 22.7 & 0.79 & 1.21 & 10.85 \\
5275 & 23.2 & 0.74 & 1.83 & 10.76 \\
\hline
\end{tabular}

${ }^{1}$ Whole-body rate of appearance of L-Met based on kinetics of L- $\left[\right.$ methyl- $\left.{ }^{2} \mathrm{H}_{3}\right] \mathrm{Met}_{\text {. }}$

${ }^{2}$ Appearance of $\mathrm{L}-\left[1-{ }^{13} \mathrm{C}\right]$ Met relative to the disappearance of $\mathrm{D}-\left[1-{ }^{13} \mathrm{C}\right] \mathrm{Met}$ : see text for calculations.

${ }^{3}$ Fractional removal of the D-enantiomer, $\mathrm{k}_{\mathrm{D}}$, or of the L-enantiomer, $\mathrm{k}_{\mathrm{L}}$, based on kinetics of $\left[1{ }^{13} \mathrm{C}\right] \mathrm{Met}$ enantiomers.

thermore, when pool size was taken into consideration, the outflow of L-Met was consistent across both studies at $21 \mathrm{mmol} / \mathrm{h}$.

High bioavailability of D-Met has been reported in mouse, rat, chick, rabbit, dog, and pig (see Lewis and Baker, 1995), with these usually assessed by comparison of $\mathrm{N}$ retention or weight gain obtained with the various enantiomers. Similarly, in sheep, a mixture of DL-Met or D-Met was as effective as L-Met to support wool growth (Doyle, 1981; Reis et al., 1989), although Doyle (1981) reported a trend toward lower S and N retention with D- versus L-Met supplementation. In cattle, postruminal infusion of DL-Met tended to result in a lower $\mathrm{N}$ retention than observed with L-Met supplementation (Titgemeyer and Merchen, 1990) but, in a second study, D-Met was $96 \%$ as efficient as LMet in supporting N retention (Campbell et al., 1996). Nonetheless, the amount of Met needed to support the observed increased $\mathrm{N}$ retention in the latter study, assuming $20 \mathrm{mg}$ of Met per g of CP (Ainslie et al., 1993), represented only slightly more than $20 \%$ of the Met supplementation. Stable isotope methodology allowed direct determination in vivo of the transformation of the D- into the L-enantiomer. In rats, conversion of D- $\left[{ }^{2} \mathrm{H}_{3}\right]$ Met into L- $\left[{ }^{2} \mathrm{H}_{3}\right]$ Met was estimated at $>90 \%$ (Hasegawa et al., 2005). With the slightly different approach used in the current study, the results confirm that in dairy cows a major fraction of the D-Met is also transformed into the L-isomer.

\section{Study 3}

Infusion of DL-Met resulted in higher arterial concentrations of total Met than with a similar dose of L-Met (Table 6), in agreement with the first study and previous observations (Titgemeyer and Merchen, 1990; Campbell et al., 1996). These higher arterial concentrations again were due to accumulation of the D-isomer, as exemplified by a $37 \%$ contribution to plasma Met, despite a contribution to total Met supply of only $20 \%$. Concentrations of D-Met tended to increase $(P=0.07)$ in the portal vein compared with arterial inflow, indicating that absorption of D-Met occurred, as previously reported in cattle (Campbell et al., 1996). This was despite a decrease $(P<0.05)$ in the D:L Met ratio in this blood vessel, due to the greater amount of L-Met absorbed from both the diet and the DL-Met infusion.

The proportion of total Met as D-Met increased $(P<$ 0.001 ) between the mammary artery and vein, from 37 to $60 \%$ (Table 6 ). Indeed, only L-Met was extracted by the mammary gland (Table 7). The lack of net removal means that even if D-Met was transported into the mammary gland the enzymes to effect transformation to L-Met were not present. In contrast, D-Met kinetics across the liver were less clear; there appeared to be hepatic removal but the fractional extraction, relative to total inflow, averaged $7.8 \%$ compared with $12.6 \%$ for L-Met (Table 7). This lower rate of extraction is supported by earlier analysis of 14 treatments where liver fractional removal of Met showed a close relationship against total liver inflow only when treatments in which rumen-protected DL-Met was supplied were removed (Lapierre et al., 2005). On a net basis, the liver and the mammary gland account for most of Met removal from the blood in the lactating dairy cow (Lapierre et al., 2005) and so the lower rate of removal of D-Met compared with L-Met would mainly originate from nonutilization by the mammary gland plus a lower hepatic extraction.

The question of removal or metabolism of D-Met by the gut can be addressed indirectly. When supply of 15 $\mathrm{g} / \mathrm{d}$ of DL-Met by either portal vein infusion (study 1 ) or via the abomasum (study 3 ) were compared within the same cow, then no differences were found for total or D-Met concentrations and neither in the proportion of total as D-Met or in the ratio of D:L Met concentrations (Tables 4 and 6, plus data not shown). This implies that any effect of the gut on either removal of D-Met or conversion to L-Met will be limited.

The current study does not answer the question of where the conversion of D-Met to L-Met occurs in the body. D-Amino acid oxidase is present in peroxisomes 
Table 6. Plasma Met concentrations and distribution between the D- and L-enantiomers in dairy cows receiving abomasal infusion of $15 \mathrm{~g} / \mathrm{d}$ of L- or DL-Met ${ }^{1}$ (study 3 )

\begin{tabular}{|c|c|c|c|c|c|}
\hline \multirow[b]{2}{*}{ Met } & \multirow{2}{*}{$\begin{array}{l}\text { Site of } \\
\text { sampling }\end{array}$} & \multicolumn{2}{|c|}{ Treatment } & \multirow[b]{2}{*}{ SEM } & \multirow[b]{2}{*}{$P$-value } \\
\hline & & L-Met & DL-Met & & \\
\hline \multirow[t]{4}{*}{ Total $(\mu M)$} & Arterial & 25.4 & 37.4 & 0.5 & 0.004 \\
\hline & Portal & 37.7 & 49.8 & 2.0 & 0.05 \\
\hline & Hepatic & 31.7 & 42.7 & 1.3 & 0.03 \\
\hline & Mammary & 12.0 & 24.3 & 0.3 & 0.002 \\
\hline \multirow[t]{4}{*}{$\mathrm{L}(\mu M)$} & Arterial & 25.4 & 23.6 & 1.0 & 0.34 \\
\hline & Portal & 37.7 & 34.0 & 2.2 & 0.35 \\
\hline & Hepatic & 31.7 & 28.2 & 1.5 & 0.25 \\
\hline & Mammary & 12.0 & 9.6 & 0.9 & 0.19 \\
\hline \multirow[t]{5}{*}{$\mathrm{D}(\mu M)$} & Arterial & 0.2 & 13.8 & & \\
\hline & Portal & $\mathrm{ND}^{2}$ & 15.8 & & \\
\hline & Hepatic & ND & 14.6 & & \\
\hline & Mammary & ND & 14.7 & & \\
\hline & SEM & - & 0.5 & & \\
\hline \multirow[t]{5}{*}{ D (\%) } & Arterial & ND & $37.1^{\mathrm{a}}$ & & \\
\hline & Portal & ND & $32.1^{\mathrm{b}}$ & & \\
\hline & Hepatic & ND & $34.4^{\mathrm{ab}}$ & & \\
\hline & Mammary & ND & $60.1^{\mathrm{c}}$ & & \\
\hline & SEM & - & 1.1 & & \\
\hline
\end{tabular}

${ }^{a-c}$ Means in a column, within a D-parameter, with a different superscript differ at $P<0.05$.

${ }^{1}$ Data are presented as LSM with pooled SEM, given for $\mathrm{n}=4 ; 8$ observations.

${ }^{2} \mathrm{ND}=$ not determined

across many tissues in mammalian species (Hamilton, 1985) with high activity in bovine kidney (Horiike and Miyake, 1971) and with the enzyme isolated from beef liver offered commercially. The disappearance of D-Met from the whole body $(3.7 \mathrm{mmol} / \mathrm{h}$; from Tables 4 and $5)$ is approximately twice that based on hepatic extraction and estimated blood flow for the same animals (Lapierre et al., 2009) and suggests that other tissues,

Table 7. Plasma Met veno-arterial concentration differences and distribution between the D- and L-enantiomers in dairy cows receiving abomasal infusion of $15 \mathrm{~g} / \mathrm{d}$ of L- or DL-Met ${ }^{1}$ (study 3 )

\begin{tabular}{|c|c|c|c|c|c|}
\hline \multirow[b]{2}{*}{ Met } & \multirow{2}{*}{$\begin{array}{l}\text { Veno-arterial } \\
\text { difference }\end{array}$} & \multicolumn{2}{|c|}{ Treatment } & \multirow[b]{2}{*}{ SEM } & \multirow[b]{2}{*}{$P$-value } \\
\hline & & L-Met & DL-Met & & \\
\hline \multirow[t]{5}{*}{ Total $(\mu M)$} & Portal-arterial & $12.5^{* *}$ & $11.2^{* *}$ & 0.8 & 0.39 \\
\hline & Hepatic-portal & $-6.1^{*}$ & $-7.1^{*}$ & 0.7 & 0.46 \\
\hline & Mammary-arterial & $-13.6^{* *}$ & $-13.2^{* *}$ & 0.3 & 0.43 \\
\hline & Liver removal/inflow ${ }^{2}(\%)$ & 11.4 & 10.4 & 0.8 & 0.49 \\
\hline & $\mathrm{AM} / \mathrm{A}^{3}(\%)$ & 53.7 & 35.0 & 1.5 & 0.02 \\
\hline \multirow{5}{*}{$\mathrm{L}(\mu M)$} & Portal-arterial & $12.5^{* *}$ & $9.5^{*}$ & 1.0 & 0.17 \\
\hline & Hepatic-portal & $-6.1^{*}$ & $-5.8^{*}$ & 0.7 & 0.79 \\
\hline & Mammary-arterial & $-13.6^{* *}$ & $-14.0^{* *}$ & 0.2 & 0.22 \\
\hline & Liver removal/inflow (\%) & 11.4 & 12.6 & 1.5 & 0.75 \\
\hline & $\mathrm{AM} / \mathrm{A}(\%)$ & 53.7 & 59.0 & 2.4 & 0.26 \\
\hline \multirow[t]{4}{*}{$\mathrm{D}(\mu M)$} & Portal-arterial & $\mathrm{ND}^{4}$ & 1.7 & 0.8 & \\
\hline & Hepatic-portal & ND & -1.2 & 0.9 & \\
\hline & Mammary-arterial & ND & 0.8 & 0.2 & \\
\hline & Liver removal/inflow (\%) & - & 7.8 & 3.4 & \\
\hline
\end{tabular}

${ }^{1}$ Data are presented as LSM with pooled SEM, given for $\mathrm{n}=4 ; 8$ observations.

${ }^{2}$ Liver removal relative to total liver inflow; see text for calculations.

${ }^{3}$ Arterio-mammary difference/arterial concentration.

${ }^{4} \mathrm{ND}=$ not determined

${ }^{* *} P<0.01 ;{ }^{*} P<0.05$ : veno-arterial differences are different from zero. 
such as the kidney, probably also play an important role.

\section{CONCLUSIONS}

This study clearly demonstrated that the Denantiomer of Met, constituting half of the Met in rumen-protected products, is highly transformed to the L-enantiomer in dairy cows. The WB rate of disappearance of D-Met is, however, much slower than that of L-Met, with the half-life of D-Met being 6 to 7 times longer than that of L-Met. The nonutilization of D-Met by the mammary gland and a lower hepatic extraction of D-Met compared with L-Met would contribute to the slower rate of disappearance. The longer half-life of D-Met could be useful as it offers the opportunity to delay the clearance of the absorbed Met and act as a potential reservoir for L-Met synthesis.

\section{ACKNOWLEDGMENTS}

The authors thank the barn staff of the Dairy and Swine Research and Development Centre for taking care of the animals, L. Croteau, V. Dostie, M. Léonard, and B. Vallerand (Agriculture and Agri-Food Canada, Sherbrooke, QC, Canada) for their dedicated technical support; P. Dubreuil (Faculty of Veterinary Medicine, Montreal University, St-Hyacinthe, QC, Canada) for splanchnic surgeries; and S. Methot (Agriculture and Agri-Food Canada, Sherbrooke, QC, Canada) for statistical analyses. The authors acknowledge the financial support from Dairy Farmers of Canada and from Agriculture and Agri-Food Canada. Part of this work was also funded by the Rural and Environmental Research and Analysis Directorate (RERAD) of the Scottish Government as part of the core grant allocations to both the Rowett Institute of Nutrition and Health, University of Aberdeen, and Biomathematics and Statistics Scotland.

\section{REFERENCES}

Ainslie, S. J., D. G. Fox, T. C. Perry, D. J. Ketchen, and M. C. Barry. 1993. Predicting amino acid adequacy of diets fed to Holstein steers. J. Anim. Sci. 71:1312-1319.

Calder, A. G., K. E. Garden, S. E. Anderson, and G. E. Lobley. 1999. Quantitation of blood and plasma amino acids using isotope dilution electron impact gas chromatography/mass spectrometry with $\mathrm{U}_{-}{ }^{13} \mathrm{C}$ amino acids as internal standards. Rapid Commun. Mass Spectrom. 13:2080-2083.

Calder, A. G., and A. Smith. 1988. Stable isotope ratio analysis of leucine and ketoisocaproic acid in blood plasma by gas chromatography/mass spectrometry. Use of tertiary butyldimethylsilyl derivatives. Rapid Commun. Mass Spectrom. 2:14-16.

Campbell, C. G., E. C. Titgemeyer, and G. St-Jean. 1996. Efficiency of D- vs L-Methionine utilization by growing steers. J. Anim. Sci. $74: 2482-2487$.
Canadian Council on Animal Care. 1993. Guide to the Care and Use of Experimental Animals. Vol. 1, 2nd ed. E. D. Olfert, B. M. Cross and A. A. McWilliam, ed. CCAC, Ottawa, ON, Canada.

Doepel, L., M. Lessard, N. Gagnon, G. E. Lobley, J. F. Bernier, P. Dubreuil, and H. Lapierre. 2006. Effect of postruminal glutamine supplementation on immune response and milk production in dairy cows. J. Dairy Sci. 89:3107-3121.

Doyle, P. T. 1981. Sulfur and methionine metabolism in sheep. V. Utilization of methionine isomers. Aust. J. Biol. Sci. 34:47-59.

Friedman, M., and M. R. Gumbmann. 1989. Dietary significance of D-amino acids. Pages 173-190 in Absorption and Utilization of Amino Acids. Vol. II. M. Friedman, ed. CRC Press Inc., Boca Raton, FL.

Gill, J. L. 1978. Design and analysis of experiments in the animal and medical sciences. Vol. 1. Iowa State Univ. Press, Ames.

Hamilton, G. A. 1985. Peroxisomal oxidases and suggestions for the mechanism of action of insulin and other hormones. Adv. Enzymol. $57: 85-178$

Hasegawa, H., Y. Shinohara, K. Akahane, and T. Hashimoto. 2005. Direct detection and evaluation of conversion of D-methionine into L-methionine in rats by stable isotope methodology. J. Nutr. 135:2001-2005.

Horiike, K., and Y. Miyake. 1971. Some properties of D-amino acid oxidase apoenzyme from beef kidney. J. Biochem. 70:877-879.

Huntington, G. B., C. K. Reynolds, and B. H. Stroud. 1989. Techniques for measuring blood flow in splanchnic tissues of cattle. J. Dairy Sci. 72:1583-1595.

Lapierre, H., R. Berthiaume, and L. Doepel. 2002. Rumen-protected amino acids: Why, what and when? Pages 144-157 in Proc. Maryland Nutrition Conference. University of Maryland, College Park.

Lapierre, H., R. Berthiaume, G. Raggio, M. C. Thivierge, L. Doepel, D. Pacheco, P. Dubreuil, and G. E. Lobley. 2005. The route of absorbed nitrogen into milk protein. Anim. Sci. 80:11-22.

Lapierre, H., L. Doepel, E. Milne, and G. E. Lobley. 2009. Responses in mammary and splanchnic metabolism to altered lysine supply in dairy cows. Animal 3:360-371.

Lewis, A. J., and D. H. Baker. 1995. Bioavailability of D-amino acids and DL-hydroxy-methionine. Pages 67-81 in Bioavailability of Nutrients for Animal: Amino Acids, Minerals, and Vitamins. Academic Press Inc., San Diego, CA.

Lobley, G. E., A. Connell, and D. Revell. 1996. The importance of transmethylation reactions to methionine metabolism in sheep: Effects of supplementation with creatine and choline. Br. J. Nutr. $75: 47-56$.

Lobley, G. E., H. Lapierre, J. Dibner, D. S. Parker, and M. VazquezAnon. 2001. HMB metabolism in ruminants. Pages 15-23 in Proc. Southwest Nutrition \& Management Conf. College of Agriculture, University of Arizona, Tucson.

Lobley, G. E., X. Shen, G. Le, D. M. Bremner, E. Milne, A. G. Calder, S. E. Anderson, and N. Dennison. 2003. Oxidation of essential amino acids by the ovine gastrointestinal tract. Br. J. Nutr. 89:617-630.

Lobley, G. E., T. J. Wester, A. G. Calder, D. S. Parker, J. J. Dibner, and M. Vazquez-Anon. 2006. Absorption of 2-hydroxy-4-methylthiobutyrate and conversion to methionine in lambs. J. Dairy Sci. 89:1072-1080.

NRC. 2001. Nutrient Requirements of Dairy Cattle. 7th rev. Natl. Acad. Sci., Washington, DC.

Patton, R. A. 2010. Effect of rumen-protected methionine on feed intake, milk production, true milk protein concentration, and true milk protein yield, and the factors that influence these effects: A meta-analysis. J. Dairy Sci. 93:2105-2118.

Preynat, A., H. Lapierre, M. C. Thivierge, M. F. Palin, J. J. Matte, A. Desrochers, and C. L. Girard. 2009. Effects of supplements of folic acid, vitamin $\mathrm{B}_{12}$, and rumen-protected methionine on whole body metabolism of methionine and glucose in lactating dairy cows. J. Dairy Sci. 92:677-689.

Reis, P. J., D. A. Tunks, and L. F. Sharry. 1989. Incorporation of abomasal and intravenous doses of $\left.{ }^{35} \mathrm{~S}\right]$ cysteine and $\left.{ }^{35} \mathrm{~S}\right]$ methionine into wool. J. Agric. Sci. 112:313-319. 
Robinson, P. H. 2010. Impacts of manipulating ration metabolizable lysine and methionine levels on the performance of lactating dairy cows: A systematic review of the literature. Livest. Sci. 127:115126.

Rulquin, H., P. M. Pisulewski, R. Vérité, and J. Guinard. 1993. Milk production and composition as a function of postruminal lysine and methionine supply: A nutrient-response approach. Livest. Prod. Sci. 37:69-90.

SAS Institute. 2008. SAS/STAT 9.2. SAS Institute Inc., Cary, NC.

Schwab, C. G. 1996. Rumen-protected amino acids for dairy cattle: Progress towards determining lysine and methionine requirements. Anim. Feed Sci. Technol. 59:87-101.
Shipley, R. A., and R. E. Clark. 1972. Tracer methods for in vivo kinetics. Academic Press, New York, NY.

Stegink, L. D. 1983. Amino acids in pediatric parenteral nutrition. Am. J. Dis. Child. 137:1008-1016.

Titgemeyer, E. C., and N. R. Merchen. 1990. Sulfur-containing amino acid requirement of rapidly growing steers. J. Anim. Sci. 68:20752083.

Wilson, F. A., J. J. G. C. van den Borne, A. G. Calder, N. O’Kennedy, G. Holtrop, W. D. Rees, and G. E. Lobley. 2009. Tissue methionine cycle activity and homocysteine metabolism in female rats: Impact of dietary methionine and folate plus choline. Am. J. Physiol. Endocrinol. Metab. 296:E702-E713. 